\title{
Peran Politik dalam Pembangunan Ekonomi Indonesia
}

\author{
Moh. Hudi \\ Ilmu Hukum \\ Universitas Islam Darul Ulum Lamongan \\ Email; m.hudi@unisda.ac.id
}

Received: 26 September 2020; Revised: 09 Oktober 2020; Accepted : 15 November 2020;

Published : December 2020; Available online : December 2020.

\begin{abstract}
Indonesia is a developing country which is one of the countries that are members of the group of world countries, including the World Trade Organization (WTO), the Asian Pacific Economic Corporation (APEC), Southeast Asia Association of South East Of Asian Nation (ASEAN) and others. Even though until now the Indonesian state in its level of economic development is not very well established. Even among ASEAN countries, Indonesia is still lagging behind other ASEAN countries. This will hamper Indonesia's growth in the medium and long term if the quality of the economy is not immediately improved.
\end{abstract}

Keywords: Political; Development; Indonesia

\section{Pendahuluan}

Perlu kita ketahui bahwa pada masa orde baru merupakan masa-masa yang krusial baik dalam sistem perpolitikan maupun sistem ekonomi. Dalam sistem politik yang otoriter menyebabkan banyak terjadinya pembelengguan disegala sektor, dimulai dari sektor politik, hukum, atau perundang-undangan, perekonomian, kebebasan pers dan lain-lain. Dengan demikian untuk mengembalikan citra atau kebijaksanaan bangsa dan negara sebagai bangsa dan negara yang besar serta memiliki kedaulatan di bidang hukum, politik dan ekonomi perlu untuk selalu meningkatkan kualitas hidupnya. Bangsa ini harus terus berkembang dan maju dalam segala bidang sesuai dengan amanat konstitusi Undang-undang Dasar Negara Republik Indonesia Tahun 1945 (selanjutnya disebut UUD 1945)

Indonsia merupakan negara berkembang yang merupakan salah satu 
negara yang tergabung dalam kelompok negara-negara dunia, diantaranya adalah World Trade Organization (WTO), Asian Pasific Economic Coorporation (APEC), Asia Tenggara Association South East Of Asian Nation (ASEAN) dan lain-lain. Meskipun sampai sekarang negara Indonesia dalam tingkat perkembangan ekonominya belum begitu mapan. Diantara negara-negara ASEAN saja Indonesia masih tertinggal dengan negara-negara ASEAN lainnya. Ini akan menghambat pertumbuhan indonesia untuk jangka menengah dan panjang kalau tidak segera ditingkatkan kualitas ekonominya.

Krisis ekonomi yang terjadi saat ini telah berkembang menjadi krisis yang rumit dan kompleks yang terkadang menimbulkan pesimisme tentang jayanya ekonomi indonesia dimasa sekarang dan yang akan datang. Saat ini indonesia masih mengalami perekonomian yang belum memuaskan dan belum tahu pasti sampai kapan perekonomian indonesia akan membaik. Banyak dari para pengamat baik politik maupun ekonomi mengatakan bahwa pembangunan ekonomi indonesia tidak didukung oleh sumber daya domestik yang kuat dan tangguh, tetapi karena didukung oleh investor asing, politik indonesia yang tidak menentu, lebih mengutamakan investor asing yang berjangka pendek dan sewaktu-waktu mereka dapat keluar dari indonesia dari pada kepentingan masyarakat untuk jangka panjang atau bahkan selamalamanya.

Kondisi perekonomian saat ini sedang tidak menentu sebagaimana tersebut di atas, telah menimbulkan beberapa faktor diantaranya adalah problem sosial yang sangat kompleks, seperti timbulnya pengangguran yang semakin meningkat, bertambahnya angka kemiskinan, produktivitas dan kualitas tenaga kerja yang rendah, usaha kecil dan menengah yang menjadi tumpuan rakyat. Disamping itu juga indonesia dihadapkan pada ekonomi global yang bergerak dari satu negara ke negara yang lain secara bebas, sehingga ketidakpastian perekonomian indonesia dalam pasar ekonomi dunia semakin tinggi. Kondisi tersebut membawa kecenderungan pada peningkatan perjanjian bilateral dan multilateral antar negara selaku pelaku ekonomi di dunia internasional yang pada akhirnya berdampak pada timbulnya hukum baru pada masing-masing negara.

Para ahli ekonomi indonesia telah memberikan pendapatnya tentang solusi terbaik untuk menyelesaikan beberapa problem yang menyangkut perbaikan 
ekonom indonesia. Ada yang menganjurkan agar ditingkatkan kerja sama ekonomi dengan dunia internasional, khususnya dengan negaranegara yang tergabung dalam ASEAN. Hal ini perlu dilaksanakan guna menyelaraskan perkembangan ekonomi dunia dengan perkembangan ekonomi negara-negara ASEAN yang penuh dengan persaingan. ${ }^{1}$

Globalisasi dewasa ini telah melahirkan berbagai kejadian atau hal baru dalam perkembangan ekonomi dunia diantaranya yaitu terjadinya era pasar bebas internasional, interdependensi sistem baik dalam bidang politik maupun bidang ekonomi, lahirnya berbagai macam lembaga ekonomi internasional, pengelompokan negara dalam kawasan ekonomi regional, maju pesatnya pelaku ekonomi trans nasional corperation dan lain-lain. Hal tersebut tidak dapat dilakukan oleh hukum yang hanya dapat dirasakan oleh orang yang berkepentingan, begitupula dengan politik dan ekonomi.

Bardasarkan hal tersebut di atas, akan dibahas tentang bagaimana peran politik dalam pembangunan ekonomi di indonesia?, dengan menggunakan metode dan pendekatan deskriptif analitis serta memberikan kasus, sehingga penggambaran tentang bagaimana peran politik dalam pembangunan ekonomi di Indonesia dapat dideskripsikan dengan baik.

\section{A. Pembangunan Ekonomi Nasional}

Pembangunan pada hakekatnya adalah upaya sistematis dan terencana oleh masing-masing maupun seluruh komponen bangsa untuk mengubah suatu keadaan dari yang kurang baik manjadi lebih baik dengan memanfaatkan berbagai sumber daya yang tersedia secara optimal, efisien, efektif dan akuntabel. Untuk meningkatkan kualitas hidup manusia dan masyarakat secara berkelanjutan. Upaya tersebut harus berisi langkahlangkah strategis, taktis dan praktis. Karena masing-masing negara memiliki usia kadaulatam, sumber daya andalan dan tantangan yang berbeda. ${ }^{2}$

Bagi bangsa Indonesia secara khusus tujuan pembangunan nasional telah digariskan dalam pembukaan UUD 1945, yaitu untuk melindungi segenap bangsa dan seluruh tumpah darah indonesia, mamajukan kesejahteraan umum, mencerdaskan kahidupan bangsa, 
dan ikut melaksanakan ketertiban dunia yang berdasarkan kemerdekaan, perdamaian abadi, dan keadilan sosial. ${ }^{3}$ Jika tujuan yang dimandatkan oleh konstitusi ini disarikan, akan tampak bahwa mandat yang diberikan negara kepada para pemangku kepentingan, khususnya penyelenggara negara dan pemerintahan di Negara Kesatuan Republik Indonesia (NKRI) adalah untuk memulihkan manusia dan kehidupan bermasyarakat mulai dari lingkup terkecil hingga ke lingkup yang besar. Sedangkan perekonomian nasional dan kesejahteraan sosial mengacu pada Pasal 33 UUD 1945 yang berbunyi:4

(1) Perekonomian disusun sebagai usaha bersama berdasar atas asas kekeluargaan;

(2) Cabang-cabang produksi yang penting bagi negara dan yang menguasai hajat hidup orang banyak dikuasai oleh negara;

(3) Bumi dan air dan kekayaan alam yang terkandung di dalamnya dikuasai oleh negara dan dipergunakan untuk sebesarbesarnya kemakmuran rakyat;

(4) Perekonomian nasional diselenggarakan berdasar atas

\footnotetext{
${ }^{3}$ Liat Preambule UUD 1945

${ }^{4}$ Lihat UUD 1945
}

demokrasi ekonomi dengan prisip kebersamaan, efisiensi keadilan, berkelanjutan, berwawasan lingkungan, kemandirian, serta dengan menjaga keseimbangan kemajuan dan kesatuan ekonomi nasional; dan

(5) Ketentuan lebih kanjut mengenai pelaksanaan pasal ini diatur dalam undang-undang.

Dengan mengacu pada kepentingan nasional, setiap kebijakan yang dipilih baik yang terkait dengan luar maupun dari dalam negeri perlu dievaluasi asas manfaatnya bagi sebesarbesarnya untuk kemakmuran rakyat. Polemik pemanfaatan sumber daya alam, pinjaman luar negeri, kepemilikan asing, investasi dan perdagangan merupakan yang dirasakan perlu untuk ditingkatkan asas manfaatnya bagi kepentingan nasional. Pembangunan dan pertumbuhan ekonomi yang berkeadilan, penajaman paradigma ini didasarkan pada esensi pembangunan bahwa pembangunan yang kita laksanakan adalah dari, oleh, dan untuk rakyat bukan segolongan orang.

Arah pembangunan tiap negara memiliki perbedaaan, karena tiap negara memiliki karakteristik dan tujuan yang berbeda. Arah kebijakan ekonommi di 
Indonesia sejak tahun 2005 menggunakan Undang-undang Nomor 17 Tahun 2007 Tentang rencana pembangunan jangka panjang nasional tahun 2005-2025, diantaranya adalah rencana pembangunan jangka panjang nasional (RPJPN), rencana pembangunan jangka menegah nasional (RPJMN), rencana kerja pemerintah.

Rencana pembangunan jangka panjang nasional (selanjutnya disebut RPJPN) terdapat dalam Undang-undang Nomor 17 Tahun 2007 Tentang rencana pembangunan jangka panjang nasional tahun 2005-2025. Rancangan tersebut sebagai dokumen perencanaan pembangunan nasional untuk periode 20 (dua puluh) tahun terhitung sejak tahun 2005 sanpai dengan tahun 2025. Rencana pembangunan jangka panjang daerah tahun 2005-2015 (yang selanjutnya disebut RPJPD) adalah dokumen perencanaan pembangunan daerah untuk periode 20 (dua puluh) tahun terhitung sejak tahun 2005 sampai dengan 2025.

Rencana pembangunan jangka menengah nasional (selanjutnya disebut RPJMN) adalah dokumen perencanaan pembangunan nasional untuk periode 5 (lima) tahunan, yaitu RPJMN tahun 20052009, RPJMN Nasional II Tahun 2010-
2014, RPJMN Nasional III Tahun 20152019, dan RPJMN IV Tahun 2020-2024. Rencana pembangunan jangka menegah daerah adalah dokumen perencanaan pembangunan daerah untuk periode 5 (lima) tahunan yang merupakan penjabaran dari visi, misi dan program kepala daerah dengan berpedoman pada RPJP daerah serta memperhatikan RPJM Nasional.

Melihat dari arah kebijakan ekonomi indonesia, seharusnya pemerintah dapat menjalankan tugas tersebut dengan baik sesuai dengan cita luhur bangsa, apabila membuat undangundang terlebih dulu melakukan penelitian atau riset secara mendalam supaya substansi dari undang-undang tersebut dapat dirasakan manfaatnya oleh rakyat, sehingga masyarakat sejahtera, mendengar keluhan yang ada terutama yang ditemukan dalam praktik, ada baiknya mendengar dari pada User, diketahui secara jelas politik hukum yang hendak diakomodasi dan dihindari sedapat mungkin aspek politisi agar amandemen undang-undang berlaku secara operasional.

Dalam menjalankan roda perekonomian tentu terdapat tantangan yang harus dihadapi, potensi yang dimiliki, serta tujuan bernegara 
sebagaimana diamanatkan dalam pembukaan UUD 1945. Menurut Bambang Prijambodo Pembangunan Indnesia dalam jangka menengah dan panjang dihadapkan pada empat tantangan pokok. ${ }^{5}$ Pertama, makin derasnya globalisasi diberbagai bidang pembangunan dan makin terintegrasinya perekonomian dunia. Globalisasi pada satu sisi menciptakan peluang yang besar bagi yang kuat dan siap, namun pada sisi lain dapat menimbulkan kerugian bagi yang lemah dan tidak siap. Hampir tidak mungkin arus globalisasi ini dihindari dengan mengisolasi diri. Sebagai bangsa yang besar ini harus dihadapi. Kedua, perubahan geo-politik dan geo-ekonomi secara bertahap dari barat ke Asia dengan berbagai implikasinya, Indonesia diharapkan mengambil peranan besar dalam proses transisi tersebut. Ketiga, meskipun pasca krisis multi dimensi tahun 1997-1998, ekonomi indonesia sudah pulih dan muncul sebagai salah satu kekuatan ekonomi dunia mendatang, era reformasi masih menyisahkan keraguan mengenai tatanan politik, sosial, dan ekonomi yang tepat dan sejalan dengan cita-cita proklamasi. Keempat, meningkatnya

${ }^{5}$ Tim Ahli Seknas Jokowi, Jalan Kemandirian Bangsa, Gramedia, Jakarta, 2014, hlm. 663. tuntutan masyarakat antara lain masalah kesenjangan serta masih adanya beberapa kelemahan mendasar dalam perekonomian indonesia yang harus dibenahi untuk menjadi negara maju.

Faktor yang mempengaruhi melambatnya ekonomi Indonesia adalah karena tingkat pendidikan tenaga kerja indonesia yang hampir separuhnya masih berpendidikan SD, kondisi infrastruktur yang kurang memadai, berbagai hambatan pokok dan ekonomi biaya tinggi, telah mengakibatkan ekonomi indonesia kalah bersaing. ${ }^{6}$ Ini akan memperlambat langkah Indonesia dalam jangka menegah panjang menjadi negara maju. daya saing ekonomi indonesia saat ini masih tertinggal dibandingkan dengan negara-negara lain. Berbagai indikator yang disusun secara global masih menempatkan indonesia pada urutan di bawah negara-negara tetangga. ${ }^{7}$

Buruknya kualitas pertumbuhan dan kepentingan ekonomi dikarenakan beberapa faktor, diantaranya adalah pertama, pertumbuhan ekonomi yang dicapai selama ini tidak merata. Pertumbuhan ekonomi masih terpusat di

6 Tim Ahli Seknas Jokowi, Ibid, hlm. 666.

7 Tim Ahli Seknas Jokowi, Ibid, hlm. 666. 
Jawa. Perputaran ekonomi di Jawa mencapai 57,63 persen dan di Sumatera mencapai 23,77 persen. Wilayah yang lain menerima sisanya. Bahkan di Bali dan Nusa Tenggara, pertumbuhan ekonomi berada dalam tren menurun sejak 3 tahun terakhir. Dari 2,73 persen di tahun 2010 dua daerah itu turun menjadi 2,65 persen di tahun 2011 dan di tahun 2012 turun lagi menjadi 2,51 persen. ${ }^{8}$

Faktor lain yang sangat dominan adalah negara telah menganggarkan dana daerah untuk mengatasi ketimpangan sosial ekonomi, namun seringkali anggaran dana yang digelontorkan ke daerah-daerah banyak yang bocor atau dikorupsi. Kondisi ini tidak terlepas dari buruknya birokrasi negara saat ini. Hal inilah yang menyebabkan dana transfer daerah menjadi tidak efisien sehingga peningkatan dana tidak diikuti dengan membaiknya kesejahteraan masyarakat daerah. Padahal belanja pegawai di seluruh provinsi hingga tingkat kabupaten dan kota mempunyai porsi 42,3 persen dari APBNP 2012. Inilah yang mengakibatkan peran desentralisasi tidak memberikan efek yang cukup besar terhadap pertumbuhan

${ }^{8}$ Ibid, hlm. 113. ekonomi daerah dan keadilan ekonomi daerah melalui terciptanya pemerataan. Disparitas pembangunan antar wilayah dan antar desa kota seharusnya tidak terjadi jika desentralisasi fiskal berjalan dengan baik. Sebab nilai transfer daerah sangat besar dan itu bisa menjadi momentum yang baik untuk menggerakkan perekonomian daerah. ${ }^{9}$

Saat ini pemerintah pusat memberikan dana ke desa-desa sebesar 1 (satu) miliar sampai 1,2 (satu miliar dua ratus juta rupiah) keseluruh Indonesia. Apabila dana tersebut berjalan dengan baik, kemungkinan besar desa seluruh Indonesia mengalami kemajuan dan kemakmuran yang pesat, namun apabila dana tersebut banyak yang bocor artinya masih banyak yang dikorupsi sehingga dana tersebut tidak dapat diserap oleh desa, maka kemanfaatan dan kesejahteraan tidak dapat dirasakan oleh masyarakat. Kemakmuran tidak lagi terwujud.

Disamping itu tingkat pendidikan dan kesehatan, perhatian perlu diberikan pada pembangunan moral, akhlak, dan budi pekerti yang tinggi, serta memiliki karakter yang kuat sebagaimana yang

9 Aunur Rofiq, Pertumbuhan Ekonomi dan Kemiskinan Kebijakan dan Tantangan Masa Depan, Republika Penerbit, Jakarta, 2014, hlm. 113. 
diamanatkan dalam pembukaan UUD 1945. Tanggung jawab mendasar bagi negara sesuai dengan amanat pembukaan UUD 1945 menuntut bahwa kemiskinan harus secepatnya dihilangkan.

Dari kasus tersebut diatas seharusnya pemerintah dapat mengevaluasi kerja pemerintah, apakah tugas pemerintah sudah sesuai dengan harapan atau tujuan yang sudah dia tentukan, apabila sudah maka berhentilah dia pada tingkat itu. Namun bila hasilnya tidak sesuai dengan harapan maupun tujuannya, dia akan kembali mengkaji apakah di dalam menentukan masalahnya itu benar atau belum, di dalam menentukan data dia belum tuntas atau belum, di dalam menganalisis dia membuat kesalahan atau tidak, di dalam menyiapkan analisis masih ada yang kurang alatnya tidak cukup atau di dalam memilih alternatif yang terbaik dia kurang teliti dan sebagainya. Proses ini harus dilakukan dengan cepat dan tepat karena dia dibatasi oleh waktu dan masih banyak mungkin masalah lain yang dia harus hadapi. ${ }^{10}$

10 Sukanto Reksohadiprodjo, Ekonomika Publik (Edisi Pertama), BPFEYogyakarta, Yogyakarta, 2013, hlm. 8.
Manurut Poppy, bagaimana membayangkan bahwa kedaulatan dan kemandirian bangsa masih kita miliki ketika pengambilan kebijakan ekonomi banyak dipengaruhi oleh intervensi negara-negara kuat pemberi utang, lembaga internasional pemberi utang, dan perusahaan-perusahaan raksasa multinasional pendongkrak besaran nilai investasi asing pada neraca modal Indonesia?, bagaimana mendefinisikan dengan jelas bagaimana sistem ekonomi yang kita jalankan pada saat apa yang akan kita jalankan adalah sebuah bangunan ekonomi yang hanya mengikuti tren kebijakan ekonomi negara-negara kuat dunia, menuruti rekomendasi kebijakan lembaga internasional, dan mematuhi konsesi ekonomi dari perusahaan raksasa dunia?, bagaimana kita dapat menegakkan kepala kita sebagai sebuah bangsa ketika kita tahu apa yang kita kosumsi di dalam negeri adalah barang atau jasa yang sangat tergantung pada bahan baku impor, barang jadi yang dihasilkan di luar negeri dan cipta karya dari perusahaan raksasa internasional?, bagaimana memiliki kepercayaan diri sebagai suatu bangsa apabila produksi dalam negeri melemah, apa yang didagangkan dalam negeri adalah sebatas hasil rakitan lokal, dan keahlian 
tegnologi tidak memiliki sepenuhnya oleh para tenaga kerja lokal?, bagaimana kita yakin bahwa kita mandiri pada saat kita tidak memiliki posisi tawar di dalam pusaran lalu lintas barang, jasa dan uang di pasar internasional?.11

Pertanyaan tersebut sangat sulit dijawab, karena untuk saat ini hal tersebut memang terjadi di negara kita, masih banyak kekurangan dan hambatan yang harus dijadikan pekerjaan rumah, baik oleh pemerintahan secara umum dan masyarakat. Untuk saat ini pemerintah seakan-akan hanya mengambil keuntungan pribadi atau golongan yang hanya dapat dirasakan dalam jangka waktu yang terbatas, tetapi untuk jangka waktu yang panjang rakyat harus menanggung kerugian dari dampak yang dilakukan oleh pemerintahan.

Menarik jika kita baca dalam kompas edisi minggu, 13 Desember 2015, publik bicara ekonomi kapitalis dan ekonomi kerakyatan, Indonesia menganut dan mengimplementasikan sistem ekonomi kapitalis dan sistem ekonomi kerakyatan. Namun dalam kenyataannya, Indonesia lebih mengimplementasikan sistem kapitalis.
Kapitali lebih mengedepankan investasi besar-besaran dan berupaya memengaruhi pemerintah agar memberikan kebijakan-kebijakan yang menguntungkan bagi perkembangan bisnisnya. Dengan berbagai fasilitas dan kemudahan dari pemerintah, perusahan mendapatkan kepentingan besar dalam waktu singkat sehingga dapat mengembangkan perusahaan melalui investasi lainnya. Ekonomi kapitalis berkembang pesat lantara perbankan sangat berminat memberikan dana kepada para pengusaha. ${ }^{12}$

Konglomerat yang tumbuh dan berkembang menjadi indikator berkenbangnya sistem ekonomi kapitalis dalam sebuah negara. Indikator lainnya antara lain makin banyaknya unjuk rasa buruh yang memperjuangkan hakhaknya belum terpenuhi terkait peningkatan kesejahteraan. Dengan orientasi keuntungan berlipat, sistem ekonomi kapitalis akan mengikis nilai kebersamaan dan gotongroyong dalam masyarakat Indonesia. Kesejahteraan buruh dikalahkan naluri untuk menguasai dan memperalat buruh yang
11 Tim Ahli Seknas Jokowi, Ibid, hlm. 645 .
${ }^{12}$ Kompas, Minggu, 13 Desember, 2015, hlm. 12 
dipandangnya sebagai alat produksi semata. ${ }^{13}$

Pemerintah selama ini tidak melakukan sesuatu yang berarti agar komoditi-komoditi utama dapat diproduksi di Indonesia. Pemerintah malah berlaku ramah terhadap produk impor. Itu berarti sama halnya membiarkan terus terjadinya ketidakadilan. Harga komoditi di negara maju bisa lebih murah karena petani diberi subsidi pertanian dan ekspor yang besar. ${ }^{14}$ Impor pangan yang besar harus disadari berdampak langsung, yaitu terkurasnya devisa negara. Dampak tidak langsung hilangnya peluang untuk menyerapkan tenaga kerja yang lebih besar di sektor pertanian/peternakan. Ketergantungan terhadap impor menempatkan Indonesia pada kondisi rawan dan dilematis.

Pemerintah masih mengambil kebijakan impor garam, padahal sumberdaya alam indonesia dua pertiga wilaya Indonesia merupakan lautan, dan Indonesia merupakan negara yang memiliki garis pantai terpanjang diseluruh dunia. Kenapa Indonesia tidak

\footnotetext{
${ }^{13}$ Ibid

14 Hatta Taliwang, Salamuddin Daeng dkk, Indonesiaku Tergadai, Institute Ekonomi Politik Soekarno Hatta, Jakarta, 2011, hlm. 66.
}

dapat mengelola garam lokal, seandainya kurang dalam kualitas kenapa tidak ditingkatkan saja kualitasnya tanpa mengimpor. Pemerintah harus mengimpor garam sebanyak 1,58 juta ton pertahun senilai Rp.900 miliar. $^{15}$

Daging sapi sampai saat ini Indonesia belum pernah mampu berswasembada. Dari kebutuhan sekitar daging sapi nasional sekitar 400.000 (empat ratus ribu) ton $(1,8$ juta ekor sapi) setahun, yang dapat dipenuhi di dalam negeri baru 65 (enam puluh enam) persen, sisanya 35 (tiga puluh lima) persen diimpor dari Australia, Amerika Serikat dan Selandia Baru senilai Rp. $\quad 4,8$ triliun. ${ }^{16}$ Padahal membiarkan impor daging sapi akan menimbulkan berbagai dampak, yaitu menghambat peningkatan pendapatan peternak dalam negeri, menghilangkan kesempatan kerja baru, menghambat pengentasan kemiskinan dan hilangnya peluang ekspor ternak.

\section{B. Peranan Politik Dalam \\ Pembangunan Ekonomi}

Demokrasi memiliki arti positif yang mengandung makna baik. Seorang pemimpin atau suatu pemerintah yang

\footnotetext{
${ }^{15}$ Ibid, hlm. 67.

${ }^{16}$ Ibid
} 
tidak menghormati demokrasi otomatis menampilkan konotasi negatif atau kurang baik. Perkataan demokrasi memang mempunyai banyak arti, namun satu pengertian yang pasti dapat kita setujui adalah bahwa demokrasi dapat dipakai untuk menunjukkan bahwa kekuasaan yang sebenar-benarnya berada di tangan rakyat. Demokrasi politik menolak sistem konsentrasi kekuasaan pada satu kelompok. Apalagi satu tangan atau sistem otoriter. Negara Indonesia sudah memiliki sistem pemerintahan yang baik dalam trias politika dimana di dalamnya terkandung nilai check and balanceses. Demokrasi politik menghendaki pemerataan kekuasaan politik, yakni kekuasaan harus berada di tangan rakyat.

Memaknai pancasila sebagai sebagai ideologi ekonomi indonesia harus disandingkan dengan prinsipprinsip lain dari ajaran Bung Karno, yaitu egalitarianisme, anti kapitalisme dan imperialisme, serta akses seluas-luasnya bagi rakyat dalam aktivitas ekonomi. Dari ketiga prinsip tersebut maka ciri dari sistem ekonomi pancasila dapat didefinisikan seperti yang dirumuskan oleh Prof. Mubyarto sebagai berikut: (1) roda kegiatan ekonomi digerakkan oleh rangsangan ekonomi, sosial, dan moral,
(2) masyarakat berkehendak kuat untuk mewujudkan kemerataan sosial, (3) nasionalisme ekonomi, (4) demokrasi ekonomi, dan (5) keseimbangan antara perencanaan nasional dan otonomi daerah. Kesemuanya menuju perwujudan keadilan sosial bagi seluruh rakyat Indonesia. Dari kelima ciri sistem Ekonomi Pancasila, bangsa dan negara Indonesia dapat berdiri kokoh dan berdaulat penuh atas kehidupan ekonominya. ${ }^{17}$

Peranan pemerintah dalam sistem perekonomian, pemerintah adalah suatu organisasi yang dibentuk untuk melaksanakan kewenangan atau kekuasaan atas mereka yang hidup bermasyarakat dan menyelenggarakan pelayanan dan pendanaan. Untuk maksud itu pemerintah menarik pajak, pemungutan lain. Pelayanan pemerintah berupa penyediaan barang dan jasa, misalnya pertahanan dan keamanan, peradilan dan pendidikan. Semula terbatas pada hal-hal itu saja, namun dengan bergulirnya waktu pemerintah memandang perlu untuk melaksanakan program-program demi kesejahteraan masyarakat, misalnya asuransi (hari tua dan pengangguran), penanggulangan

\footnotetext{
17 Tim Ahli Seknas Jokowi, Ibid,
} hlm. 648 . 
kebakaran, penyediaan angkutan, kesehatan dan lain-lain. ${ }^{18}$

Pemerintah menyediakan barang publik melalui proses politik, yang mungkin sederhana, mungkin juga cukup rumit. Penyediaan barang publik melengkapi penyediaan barang swasta yang semuanya dimaksudkan untuk mensejahterakan kehidupan bangsa. Bagaimana peranan pemerintah dapat pula gagal seperti halnya swasta apabila pemerintah itu "kebablasan" di dalam fungsinya, misalnya merasa mewakili rakyat dan menentukan barang dan jasa publik yang sebenarnya tidak dikehendaki masyarakat dan terlalu jauh mencampuri/mengatur aspek kehidupan masyarakat. 19

Jika demokrasi ekonomi unsur utamanya mengandung usaha penghapusan kemiskinan absolut, maka baik sistem liberal dengan konsep negara kesejahteraannya maupun negara komunis dengan prinsip sama rata sama rasa ternyata sudah mampu menyadari dan berusaha melaksanakan demokrasi ekonomi itu. ${ }^{20}$ Keduanya dilandaskan

${ }^{18}$ Sukanto Reksohadiprodjo, Ibid, hlm. 36 . hlm. 36.

${ }^{19}$ Sukanto Reksohadiprodjo, Ibid,

${ }^{20}$ Haris Munandar, Pembangunan Politik Situasi Global, dan Hak Asasi Di pada fungsi negara (pemerintah) yang harus mengatur kehidupan dalam masyarakat dan serta berusaha untuk menciptakan keseimbangan diantara golongan-golongan dalam masyarakat tertentu. ${ }^{21}$ Akan tetapi lebih baik sistem yang diambil seharusnya sesuai dengan kultur dan kebudayaan masyarakat indonesia.

Dalam teori-teori pembangunan, pembagian kerja internasional secara ideal dibagi menjadi dua bagian, bagian bumi utara dan bagian bumi selatan, bagian bumi utara dianggap sebagai bagian negara-negara yang maju, sedangkan bagian bumi selatan dianggap sebagai negara-negara yang berkembang. Negara-negara maju tidak dapat mengembangkan industrinya tanpa bantuan negara-negara berkembang karena negara-negara berkembang yang memiliki barang primer, begitu pula sebaliknya negara-negara berkembang membutuhkan negara-negara maju untuk mengolah barang primer. Keduanya tidak dapat dipisahkan atau simbiotik mutualistik. Namun dalam praktiknya ternyata terdapat "gap". Banyak negara-negara yang maju Indonesia (Kumpulan Esai Guna Menghormati Prof. Miriam Budiarjo), PT Gramedia Pustaka Utama, Jakarta, 1994, hlm. 137.

${ }^{21}$ Haris Munandar, Ibid, 137. 
memanfaatkan

negara-negara

berkembang, sehingga negara yang berkembang sulit untuk maju. Negaranegara berkembang seakan-akan terkena ciuman yang mematikan dari negaranegara yang maju. ${ }^{22}$

Dari situ seharusnya pemerintah harus lebih jelih lagi dalam menjalin hubungan kerja sama dengan negara asing, terutama terhadap negara-negara yang super power sehingga negara tidak lagi dirugikan oleh kerja sama akibat kontrak yang telah dibuat. Keputusan yang dibuat pemerintah harus menyangkut tujuan masyarakat, dapat pula menyangkut kebijakan-kebijakan untuk mencapai tujuan tersebut. ${ }^{23}$ Kontrak yang dibuat oleh pemerintah seharusnya mengacu kepada pancasila dan UUD 1945 sehingga kemanfaatannya benar-benar dapat dinikmati oleh rakyat secara luas.

Dewasa ini masih sangat banyak peraturan perundang-undangan di sektor ekonomi, politik, sosial, dan kesejahteraan rakyat, terutama setelah tahun 1998, hanya saja banyak peraturan

22 Pak Nandang, Power Point Sekaligus Keterangan Waktu Kuliah, Kamis, 10 Desember 2015.

${ }^{23}$ Miriam Budiardjo, Dasar-Dasar Ilmu Politik, PT. Gramedia, Jakarta, 2010, hlm. 19. perundang-undangan tersebut dianggap mati karena tidak berjalan sebagaimana yang diharapkan. Penyebabnya adalah pembuatan peraturan perundangundangan dilakukan terburu-buru, tidak dilakukan riset mendalam dengan naskah akademik yang baik (lebih mementingkan adanya peraturan perundang-undangan daripada esensi yang diatur). Penyebab yang lain adalah budaya hukum masyarakat Indonesia yang belum sesuai dengan nilai-nilai yang diatur dalam berbagai undangundang yang telah dibuat. ${ }^{24}$

Seharusnya Undang-undang yang tidak sesuai dengan perekonomian dan kebutuhan masyarakat segera diamandemen, amandemen terhadap peraturan perundang-undangan tersebut dapat dibagi menjadi lima kategori, Pertama, untuk memperjelas ketentuan yang mengundang multi-interpretation. kedua, amandemen dilakukan untuk lebih menyesuaikan antara nilai-nilai yang ada dalam masyarakat dengan peraturan perundang-undangan termasuk kesiapan infrastruktur pendukung peraturan perundangundangan. Ketiga, untuk memperbaiki substansi, termasuk prinsip yang diatur. Misalnya pengaturan tentang pengadilan

\footnotetext{
${ }^{24}$ Pak Nandang, Ibid
} 
niaga dalam Undang-undang kepailitan mengingat niaga juga digunakan dalam sengketa di bidang HAKI. Keempat, untuk memperbaiki prosedur. Misalnya ketentuan dalam Undang-undang persaingan. Kelima, untuk lebih meyakinkan investor untuk melakukan investasi di Indonesia, misalnya, peraturan perundang-undangan di bidang perseroan terbatas, pasar modal, otonomi daerah, pajak daerah, pertambangan dan investasi. ${ }^{25}$

\section{Hubungan Politik Dan \\ Pembangunan Ekonomi}

Keberadaan

pemerintah

merupakan perwujudan dari legitimasi kekuasaan dan kewenangan untuk mengatur kehidupan berbangsa dan bernegara dalam batas-batas yang dimungkinkan oleh konstitusi. Pada sisi yang lain, pemerintah memiliki tujuantujuan yang hendak dicapai. Oleh karena itu, bertolak dari aspek ini, pembahasan mengenai peranan pemerintah memerlukan tinjauan positif maupun normatif. $^{26}$

\footnotetext{
25 Ibid

${ }^{26}$ Haris Munandar, Pembangunan Politik Situasi Global, dan Hak Asasi di Indonesia (Kumpulan Esai Guna Menghormati Prof. Miriam Budiarjo), PT Gramedia Pustaka Utama, Jakarta, 1994, hlm. 160 .
}

Tinjauan dari aspek politik positif meliputi berbagai kekuatan dan keterbatasan pemerintah dalam menghimpun serta menyalurkan danadana yang berasal dari dalam negeri (khususnya masyarakat domestik) maupun luar negeri, serta kebijakan fiskal sebagai salah satu ujung tombak dalam kegiatan pengelolaan perekonomian nasional. ${ }^{27}$ Adapun tinjauan dari aspek normatif meliputi pemilihan prioritas jenis-jenis penerimaan (pajak dan jenis-jenis penerimaan lainnya) maupun penentuan target serta prioritas dengan mempertimbangkan segenap keadaan dan kecenderungan-kecenderungan di bidang ekonomi, sosial, dan politik. ${ }^{28}$

Pembangunan politik adalah bagian yang tak terpisahkan dari pembangunan nasional indonesia. Keberhasilan-keberhasilan dalam pembangunan politik jelas menentukan terciptanya iklim yang kondusif bagi keberhasilan pembangunan nasional secara keseluruhan, sebaliknya keberhasilan pembangunan diberbagai bidang lainnya seperti: ekonomi, sosial dan budaya juga akan memperlancar pembangunan politik. Kegagalan dalam

\footnotetext{
27 Ibid, 160

${ }^{28}$ Ibid, 160.
} 
pembangunan politik sudah pasti akan menganggu pembangunan nasional secara keseluruhan. Dapat dikatakan bahwa keberhasilan pembangunan politik merupakan persyaratan bagi keberhasilan pembangunan nasional. Pembangunan politik tersebut membentuk berbagai wahana yang mutlak diperlukan utuk menggerakkan roda pembangunan nasional.

Masalah utama dalam pembangunan politik negara-negara yang sedang berkembang adalah pencarian format demokrasi yang cocok dengan nilai-nilai budaya masyarakatnya sendiri. Format demokrasi tersebut harus dicari dan diciptakan sendiri karena demokrasi liberal seringkali tidak sesuai dengan nilai-nilai masyarakatnya. Indonesia adalah salah satu contoh dalam kasus ini. Dengan demikian, masalah utama yang harus dihadapi oleh bangsa indonesia adalah penentuan format demokrasi yang akan digunakan (yakni yang disebut dengan demokrasi pancasila). ${ }^{29}$ Bagian yang paling penting dari penentuan format tersebut adalah pengidentifikasian demokrasi pancasila sehingga struktur dan mekanisme kerjanya jelas, pasti dan praktis, disamping mengandung keunggulan- keunggulan yang benar-benar nyata dibandingkan dengan jenis-jenis demokrasi lainnya.

\section{Penutup}

Dari penjelasan di atas dapat ditarik garis merah, bahwasannya dalam perkembangan ekonomi di Indonesia banyak dipengaruhi oleh faktor-faktor yang lain, diantaranya adalah faktor politik, globalisasi atau pasar bebas, sistem ekonomi kapitalis dan lain-lain. Perkembangan ekonomi juga terdapat tantangan yang harus segera diselesaikan sepertihalnya politik yang harus pro rakyat bukan sebaliknya malah pro terhadap pelaku modal asing yang tidak memperdulikan nasib rakyat, tetapi hanya mengambil keuntungan saja.

Indonesia belum mandiri dalam hal memenuhi kebutuhan rakyatnya, terbukti dengan banyaknya barangbarang yang masih impor, bahkan dalam hal pangan Indonesia masih impor, padahal jika pemerintah serius ingin mensejahterakan masyarakatnya, pemerintah dapat mendayagunakan kemampuan masyarakat. Menswasembadakan hal-hal yang dianggap mampu dilakukan oleh pemerintah dan masyarakatnya. Sehingga negara tidak selalu bergantung pada negara lain. 
Mencari kekurangan-kekurangan dan kekurangan tersebut dapat dicarikan alternatif atau solusinya. Agar masalah yang telah terjadi dapat segera diselesaikan. Pemerintah tidak hanya duduk manis dalam kantor, tetapi harus terjun kelapangan untuk melihat atau mengawasi para pekerja atau pengusaha, biar tidak ada kejadian yang merugikan pekerja atau masyarakat.

Masalah politik, pemerintah harus membuat kebijakan atau keputusan sesuai dengan arah rencana pembangunan jangka menengah nasional, Rencana pembangunan jangka menegah daerah dan program kepala daerah dengan berpedoman pada RPJP daerah serta memperhatikan RPJM Nasional. Arah tersebut harus berkiblat kepada pancasila dan UUD 1945. Kebijakan yang harus diambil oleh pemerintah harus benar-benar sesuai dengan keadaan atau kepentingan masyarakatnya, bukan hanya kepentingan pribadi atau kelompok.

Pemerintah harus dapat membuat sistem pembangunan ekonomi Indonesia sesuai denga ciri khas, karakter dan kultur masyarakat. Karena masyarakat Indonesia tidak mungkin dapat disamakan dengan sistem pembanguanan ekonomi asing. Setiap negara pasti memiliki kebudayaan, kebiasaan atau kultur yang berbeda. Sehingga cita-cita bangsa yaitu untuk melindungi segenap bangsa dan seluruh tumpah darah indonesia, mamajukan kesejahteraan umum, mencerdaskan kahidupan bangsa, dan ikut melaksanakan ketertiban dunia yang berdasarkan kemerdekaan, perdamaian abadi, dan keadilan sosial dapat terlaksana.

Pemerintah harus selalu aktif atau update terhadap kepentingan bangsa dan negara, apabila terdapat peraturan perundang-undangan yang usang atau tidak sesuai lagi dengan keadaan masyarakat dan jamannya, maka pemerintah segera mengamandemen atau membuat aturan baru yang sesuai dengan keadaan di masyarakat. Peraturan perundang-undangan harus dibuat sesuai dengan kebutuhan masyarakat bukan kepentingan pengusaha atau malah pesanan dari pemodal atau pelaku bisnis asing yang hanya mengambil keuntungan semata.

Sebelum membuat peraturan perundang-undangan yang baru pemerintah harus melakukan penelitian atau riset secara mendalam, sehingga peraturan perundang-undangan yang dibuat dapat dijalankan dengan baik. Pembuatan Undang-undang betul-betul mengcover seluruh kegiatan yang ada 
dalam lapangan. Pemerintah dapat menerima masukan dari rakyat dalam hal memasukkan atau menentukan isi/substansi dalam pembuatan Undangundang.

Hubungan politik dan ekonomi harus harmoni saling bergantung atau berhubungan satu sama lain, supaya kepastian hukum, keadilan, dan kemanfaatan dapat dirasakan secara langsung oleh seluruh bangsa Indonesia. Pembangunan ekonomi tidak dapat berdiri sendiri, dikhawatirkan pelaku ekonomi semenah-menah dalam menjalankan perekonomiannya, begitu pula dengan politik tidak dapat berdiri sendiri, karena politik sebagai pembuat kebijakan atau keputusan harus menjamin perekonomian dapat berjalan dengan baik sesuai dengan cita-cita luhur bangsa dan negara indonesia sesuai dengan konstitusi indonesia yakni pancasila dan UUD 1945.

\section{Daftar Pustaka}

Undang-undang Dasar Tahun 1945

Peraturan Presiden Republik Indonesia

Nomor 2 Tahun 2015

Rofiq, Aunur, Pertumbuhan Ekonomi dan Kemiskinan Kebijakan dan Tantangan Masa Depan, Republika Penerbit, Jakarta, 2014.
Reksohadiprodjo, Sukanto, Ekonomika Publik (Edisi Pertama), BPFEYogyakarta, Yogyakarta, 2013.

Jokowi, Tim Ahli Seknas, Jalan Kemandirian Bangsa, Gramedia, Jakarta, 2014.

Salamuddin, Hatta Taliwang, Daeng dkk, Indonesiaku Tergadai, Institute Ekonomi Politik Soekarno Hatta, Jakarta, 2011.

Pak Nandang, Power Point Sekaligus Keterangan Waktu Kuliah.

Budiardjo, Miriam, Dasar-Dasar Ilmu Politik, PT. Gramedia, Jakarta, 2010.

Munandar, Haris, Pembangunan Politik Situasi Global, dan Hak Asasi Di Indonesia (Kumpulan Esai Guna Menghormati Prof. Miriam Budiarjo), PT Gramedia Pustaka Utama, Jakarta, 1994.

Kompas, Minggu, 13 Desember, 2015. 